JURNAL BASICEDU

Research \& Learning in Elementary Education

https://jbasic.org/index.php/basicedu

\title{
PENGARUH PROGRAM POJOK LITERASI TERHADAP MINAT BACA MAHASISWA PGSD FKIP UIR
}

\author{
Febrina Dafit ${ }^{1}$, Dea Mustika ${ }^{2}$, Ningrum Melihayatri ${ }^{3}$ \\ Universitas Islam Riau, Riau, Indonesia ${ }^{1,2,3}$ \\ Email: ,febrinadafit@edu.uir.ac.id, deamustika@edu.uir.ac.id²
}

\begin{abstract}
Membaca buku merupakan salah satu aktivitas belajar yang efektif untuk memperoleh ilmu dan pengetahuan, namun pada kenyataannya, permasalahan yang masih ditemukan sampai saat ini adalah rendahnya minat membaca pada mahasiswa. Penelitian ini bertujuan untuk mendeskripsikan kondisi minat baca mahasiswa PGSD FKIP UIR setelah terbentuknya program pojok literasi dan menelaah pengaruh program pojok literasi terhadap minat baca mahasiswa PGSD FKIP UIR. Penelitian ini adalah penelitian analisis deskriptif dengan pendekatan kuantitatif. Untuk mengetahui pengaruh program pojok literasi terhadap minat baca mahasiswa PGSD FKIP UIR, maka peneliti menggunakan analisis data regresi linear sederhana. Dari hasil penelitian diperoleh bahwa program pojok literasi memberikan pengaruh yang signifikan terhadap minat baca mahasiswa. Rata-rata minat baca mahasiswa adalah 107,39 dengan kategori baik dan memiliki persentase $83,89 \%$. Program pojok literasi memberikan pengaruh pada minat baca mahasiswa dilihat dari aspek semangat dalam membaca buku, kesadaran sebagai mahasiswa untuk membaca buku, kesadaran akan pentingnya buku, ketertarikan untuk membaca buku, ketertarikan terhadap buku bacaan, memanfaatkan waktu untuk membaca buku, memilih buku bacaan, keinginan mencari sumber bacaan buku. Minat baca mahasiswa juga sangat berkaitan dengan kesadaran mahasiswa untuk membaca. Apabila mahasiswa sadar dengan membaca maka akan menambah pengetahuan maka minat baca mahasiswa juga akan meningkat.
\end{abstract}

Kata Kunci: program pojok literasi, minat baca

\begin{abstract}
Reading books is one of the effective learning activities to gain knowledge and knowledge, but in reality, the problem that is still found today is the low interest in reading to students. This study aims to describe the condition of reading interest of PGSD FKIP UIR students after the formation of the literacy corner program and examine the effect of the literacy corner program on the reading interest of PGSD FKIP UIR students. This research is a descriptive analysis research with quantitative approach. To find out the effect of the literacy corner program on the reading interest of PGSD FKIP UIR students, the researchers used simple linear regression data analysis. From the results of the study it was found that the literacy corner program had a significant influence on students' reading interest. The average reading interest of students is 107.39 with a good category and has a percentage of $83.89 \%$. Literacy corner program gives an influence on students' reading interest viewed from aspects of enthusiasm in reading books, awareness as a student to read books, awareness of the importance of books, interest in reading books, interest in reading books, utilizing time to read books, choosing reading books, desires looking for sources to read books. Student interest in reading is also closely related to student awareness to read. If students are aware of reading it will increase knowledge, students' interest in reading will also increase
\end{abstract}

Keywords: literacy corner program, interest in reading

@Jurnal Basicedu Prodi PGSD FIP UPTT 2020

$\triangle$ Corresponding author :

Address :-

Email :-

ISSN 2580-3735 (Media Cetak)

Phone :- 
117 Pengaruh Program Pojok Literasi Minat Baca Mahasiswa PGSD FKIP UIR - Febrina Dafit, Dea Mustika, Ningrum Melihayatri

\section{PENDAHULUAN}

Membaca merupakan salah satu kegiatan yang sangat penting bagi seorang mahasiswa di dalam memperoleh pengetahuan dan informasi. Namun, pada saat ini minat baca di kalangan mahasiswa masih rendah. Rendahnya minat baca mahasiswa tersebut mengakibatkan rendahnya kemampuan kognitif di kalangan mahasiswa. Mahasiswa lebih cendrung tertarik menggunakan media sosial dan game dari pada membaca buku.

Menurut pengamatan penulis, minat baca mahasiswa PGSD FKIP UIR juga disebabkan karena kebanyakan mahasiswa tidak memiliki buku serta sulitnya menemukan buku ke-SD-an di perpustakaan universitas. Ini terlihat berdasarkan hasil survey dan data yang penulis peroleh dari petugas perpustakaan Universitas Islam Riau.

Ketika mahasiswa di berikkan tugas, mereka tidak mampu menyelesaikan tugas tepat waktu dan tidak sesuai dengan topik yang diberikan. Mahasiswa beralasan sulitnya menemukan referensi buku-buku untuk tugas mata kuliah yang diberikan dosen. Dengan demikian, wajar saja kalau mahasiswa PGSD FKIP UIR tidak memiliki kebiasaan membaca yang memadai. Persoalan minat baca pada mahasiswa dan masyarakat Indonesia adalah masalah yang klasik dan memprihatinkan. Berdasarkan studi Most Littered Nation In the World yang dilakukan oleh Central Connecticut State Univesity pada Maret 2016 lalu, minat baca Indonesia dinyatakan menduduki peringkat ke60 dari 61 negara (kompas.com). Dari hasil penelitian tersebut banyak gerakan membaca buku di kampus-kampus Indonesia sudah mulai marak digerakan. Salah satunya adalah pojok literasi. Literasi akan menjadi solusi bagi civitas akademika kampus, terkhususnya bagi mahasiswa baru untuk menanamkan pola atau ciri mahasiswa sesungguhnya. Masa peralihan dari siswa menjadi mahasiswa adalah proses yang tersulit dalam hidup. Karena pola pikir dan gaya hidup serta metode pembelajaran sangat berbeda antara masa SMA dengan Perguruan Tinggi.

Di saat peralihan inilah jati diri sendiri ditemukan. Sesorang akan terlihat sifat aslinya di masa-masa mengenyam pendidikan di Perguruan Tinggi. Mungkin akan berbeda dengan sifat yang sebelumnya. Itupun juga tergantung pada pergaulan dan sudut pandang seseorang. Oleh karena itu, penguasaan literasi dalam segala aspek kehidupan memang menjadi tulang punggung kemajuan peradaban suatu bangsa. Tidak mungkin menjadi bangsa yang besar, apabila hanya mengandalkan budaya oral yang mewarnai pembelajaran di lembaga sekolah maupun perguruan tinggi. Mahasiswa harus dan bahkan wajib banyak membaca, karena dengan membaca, mahasiswa cenderung mudah menyampaikan gagasan, berpengetahuan luas dan merangsang penalaran kritis.

Sebagaimana hasil pengamatan peneliti selama menjadi dosen di PGSD FKIP UIR minat baca dan pemahaman bacaan mahasiswa memprihatinkan. Bagaimana tidak, saat diberikan pertanyaan bekal apa saja yang mereka bawa saat mengikuti perkuliahan semua tidak bisa menjawab dan cenderung diam. Hampir seluruh mahasiswa menunjukkan bahwa mereka datang hanya dengan niat tanpa menyiapkan atau membaca materi yang sudah ada atau bahkan yang akan mereka terima ketika perkuliahan. Hal ini tentu sangat menganggu kegiatan perkuliahan yang seharusnya dapat berlangsung dengan aktif tetapi menjadi pasif. Bahkan ketika mahasiswa 
presentasi untuk diskusi kelompok, mereka tidak memahami dengan baik materi yang mereka presentasikan karena mereka tidak membaca materi sebelum presentasi.

Berbagai langkah dilakukan untuk menumbuhkan minat baca mahasiswa, salah satunya dengan budaya literasi. Menurut Alfarikh (2017:966) beberapa cara yang dapat dilakukan dalam menumbuhkan budaya literasi di kalangan pelajar dan mahasiswa adalah dengan menggunakan beberapa program, yakni e-pustaka, mentoring kata, dan arisan kata. Pemerintah juga sudah mengembangkan berbagai cara supaya minat baca pelajar bisa meningkat dan lebih baik, salah satunya dengan gerakan literasi dan pojok literasi

Gerakan literasi dan pojok literasi memperkuat gerakan penumbuhan budi pekerti sebagaimana dituangkan dalam Peraturan Menteri Pendidikan dan Kebudayaan Nomor 23 Tahun 2015. Salah satu program di dalam gerakan tersebut adalah "kegiatan 15 menit membaca buku non pelajaran sebelum waktu belajar dimulai”. Program ini dilaksanakan untuk menumbuhkan minat baca di kalangan pelajar dan mahasiswa untuk meningkatkan keterampilan membaca agar pengetahuan dapat dikuasai secara lebih baik. Materi baca berisi tentang nilai-nilai budi pekerti, berupa kearifan lokal, nasional, dan global yang akan disampaikan sesuai dengan jenjang pendidikan peserta didik.

Pojok literasi merupakan salah satu langkah di dalam menumbuhkan minat baca di kalangan mahasiswa, yang berfungsi sebagai penyedia bahan bacaan ilmu pengetahuan serta sumber informasi bagi mahasiswa itu sendiri. Sejalan dengan hal ini, peneliti juga tertarik untuk membawa gerakan tersebut pada sebuah program studi di tingkat Perguruan Tinggi yaitu Pendidikan Guru Sekolah Dasar. Tujuan dari penelitian ini secara umum adalah mendeskripsikan pengaruh pojok literasi terhadap minat baca mahasiswa PGSD FKIP UIR. Sedangkan tujuan khusus dari penelitian ini adalah mendeskripsikan kondisi minat baca mahasiswa PGSD FKIP UIR yang belum berkunjung ke pojok literasi dan menelaah pengaruh program pojok literasi terhadap minat baca mahasiswa PGSD FKIP UIR.

Literasi dikonsepkan dalam dua bidang utama yaitu bidang membaca dan menulis permulaan. Menurut Riley (2006: 12) literasi merupakan dasar keberhasilan dalam pembelajaran. Hubungan antara keberhasilan pembelajaran dengan tingkat melek huruf terjadi melalui kurikulum dan proses pembelajaran yang terjadi di sekolah. Sejalan dengan pendapat tersebut, menurut Abidin (2014: 181) literasi berkembang dan digunakan dalam kajian bidang ilmu lain yang terintegrasi dengan ilmu bahasa sebagai alat untuk memperoleh dan mengkomunikasikan informasi. Dalam bidang ilmu bahasa, dikenal dengan istilah literasi membaca dan literasi menulis.

Literasi membaca adalah kemampuan memahami, menggunakan, dan merefleksi teks melalui pelibatan langsung untuk memperoleh pengetahuan dalam rangka mencapai tujuan tertentu dan untuk berpartisipasi dalam masyarakat (Morocco, 2008: 11). Literasi adalah kemampuan seseorang dalam mengolah dan memahami informasi saat melakukan proses membaca dan menulis. Pojok literasi adalah pojok atau tempat yang menyediakan buku-buku untuk dibaca dan dipinjam, serta fasilitas 
memudahkan dalam akses internet. Pojok literasi merupakan gerakan yang dicanangkan dosen PGSD FKIP UIR. Agenda ini dilaksanakan dengan tujuan membantu mahasiswa dalam mencari referensi perkuliahan dan untuk menumbuhkan kesadaran membaca mahasiswa dari maraknya penggunaan media sosial yang tidak terkendali. Pojok literasi adalah upaya untuk meningkatkan kemampuan membaca dan menulis mahasiswa, serta meningkatkan mutu pendidikan.

Upaya menanamkan budaya literasi agar seorang anak dapat mengembangkan kemampuan membacanya adalah dengan cara pembiasaan membaca di rumah dan sekolah. Sehingga dengan adanya kemampuan membaca, kemampuan menulis seseorang tentu saja akan tumbuh. Membudayakan kebiasaan membaca harus dilatih secara kontinyu. Dengan demikian, kemampuan literasi mampu menjadi jantung dari semua proses pendidikan mulai dari pendidikan prasekolah sampai ke perguruan tinggi.

Salah satu cara untuk menjadikan literasi sebagai jantung dalam proses pendidikan adalah dengan menyediakan buku-buku di sekolah dan perguruan tinggi. Artinya membentuk budaya literasi mahasiswa, perguruan tinggi menyediakan buku-buku yang dapat diakses tidak hanya terbatas pada buku paket dan perkuliahan. Buku-buku yang disediakan dalam pojok literasi bisa tentang pendidikan, ilmu pengetahuan, buku fiksi, buku koleksi mahasiswa sendiri, dan beberapa karya mahasiswa yang bernilai seni agar memiliki kesan lebih indah. Sehingga mereka dapat bertukar pinjam dengan teman-teman.

Dalam Kamus Besar Bahasa Indonesia (Depdiknas, 2001: 744), kata minat memiliki arti kecenderungan hati yang tinggi terhadap sesuatu gairah, keinginan. Jadi harus ada sesuatu yang ditimbulkan, baik dari dalam dirinya maupun dari luar untuk menyukai sesuatu. Hal ini menjadi sebuah landasan penting untuk mencapai keberhasilan sesuatu karena dengan adanya minat, seseorang menjadi termotivasi tertarik untuk melakukan sesuatu.

Minat ditandai dengan rasa suka dan terkait pada suatu hal atau aktivitas tanpa ada yang menyuruh. Artinya, harus ada kerelaan dari seseorang untuk melakukan sesuatu yang disukai. Dengan demikian, timbulnya minat terjadi karena adanya penerimaan akan suatu hubungan antara diri sendiri dengan sesuatu diluar dirinya. Semakin kuat atau semakin besar hubungan tersebut maka semakin dekat minat seseorang.

Secara sederhana minat berarti kecenderungan dan kegairahan yang tinggi atau ke inginan yang besar terhadap sesuatu. Minat dipahami dan dipakat oleh orang selama ini untuk dapat mempengaruhi kualitas hasil belajar (Syah, 2004:136). Rahim (2007:28) mengemukakan bahwa minat baca adalah keinginan yang kuat disertai usaha-usaha seseorang untuk membaca. Orang yang mempunyai minat membaca yang kuat akan diwujudkannya dalam kesediaannya untuk mendapat bahan bacaan dan kemudian membacanya atas kesadarannya sendiri. Rahim (2007: 29) juga mengemukakan bawa minat membaca seorang anak perlu sekali dikembangkan. Kemudian Sumadi (dalam Sudiana, 2004:) mengungkapkan bahwa minat baca adalah kecenderungan jiwa yang mendorong seseorang berbuat sesuatu terhadap membaca. Minat baca ini ditunjukkan oleh adanya keinginan yang kuat untuk melakukan kegiatan membaca. 
120 Pengaruh Program Pojok Literasi Minat Baca Mahasiswa PGSD FKIP UIR - Febrina Dafit, Dea Mustika, Ningrum Melihayatri

Hurlock (1980:116) mengemukakan bahwa minat sendiri terdiri dari dua aspek, yaitu aspek kognitif dan aspek afektif. Aspek Kognitif didasari pada konsep perkembangan di masa anak-anak mengenai hal-hal yang menghubungkannya dengan minat. Minat pada aspek ini berpusat pada apakah hal yang diminati akan menguntungkan dan mendatangkan kepuasan pribadi. Aspek Afektif atau emosi yang mendalam merupakan konsep yang menampakkan aspek kognitif dari minat ditampilkan dalam sikap terhadap kegiatan yang diminati akan terbangun

Berdasarkan uraian tersebut di atas, maka penulis menyimpulkan bahwa aspek minat membaca meliputi: 1) perasaan senang dengan kegiatan membaca, 2) kebutuhan akan kegiatan membaca, 3) keinginan mencari bahan bacaan, 4) keinginan melakukan kegiatan membaca, dan 5) ketertarikan untuk membaca.

\section{METODE}

Populasi dari penelitian ini adalah seluruh mahasiswa PGSD FKIP UIR yang berkunjung ke pojok literasi, jumlah pengunjung adalah 37 orang. Teknik pengambilan sampel dalam penelitian ini adalah dengan menggunakan total sampling. Maka jumlah sampel pada penelitian ini adalah 37 orang, terdiri dari 33 orang perempuan, dan 4 orang laki-laki.

Metode penelitian ini adalah analisis deskriptif dengan pendekatan kuantitatif. Metode analisis deskriptif digunakan pada penelitian ini karena tujuan penelitian adalah mendeskripsikan pengaruh program pojok literasi terhadap minat baca mahasiswa PGSD FKIP UIR. Menurut Sugiyono (2014:147) metode deskriptif adalah suatu metode yang digunakan untuk menggambarkan atau menganalisis suatu hasil penelitian tetapi tidak digunakan untuk membuat kesimpulan yang berlaku untuk umum atau generalisasi.

Secara garis besar, pembuatan alur penelitian untuk memudahkan pemahaman pembaca terhadap pelaksanaan penelitian yang dilakukan peneliti. Adapun alur penelitiannya yaitu sebagai berikut

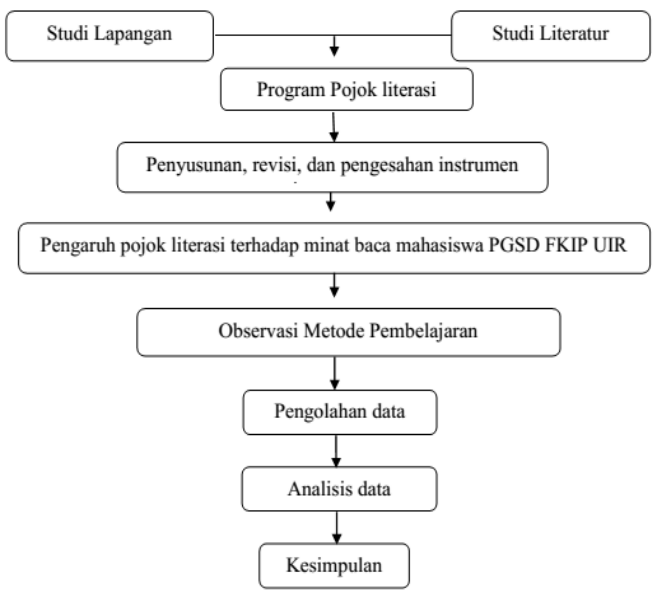

Gambar 1. Alur Penelitian

Instrumen yang digunakan dalam penelitian ini adalah angket atau kuesioner. Menurut Chaplin (dalam Rosintaunesa, 2018) angket merupakan satu set pertanyaan yang berurusan dengan satu topik tunggal yang saling berkaitan, yang harus dijawab oleh subjek. Angket yang digunakan berisi pernyataan-pernyataan tertulis, sehingga dalam mengisi angket, responden memberikan tanda checklist pada kolom yang telah disediakan dan jawaban yang sesuai. Angket yang digunakan dalam penelitian ini menggunakan skala bertingkat, dengan menggunakan modifikasi likert. Menurut Sugiyono (2014:93) skala Likert dapat digunakan untuk "mengukur sikap, pendapat dan persepsi seseorang atau sekelompok orang tentang fenomena sosial". Dalam peneltian ini, fenomena sosial yang ditetapkan secara spesifik oleh peneliti adalah minat baca mahasiswa PGSD 
121 Pengaruh Program Pojok Literasi Minat Baca Mahasiswa PGSD FKIP UIR - Febrina Dafit, Dea Mustika, Ningrum Melihayatri

FKIP UIR, yang selanjutnya disebut sebagai variabel penelitian.

Dengan skala Likert, maka variabel yang akan diukur dijabarkan menjadi subvariabel penelitian, kemudian indikator variabel. Selanjutnya, indikator tersebut dijadikan titik tolak untuk menyusun item-item instrumen yang dapat menjadi pertanyaan atau pernyataan. Penelitian ini menggunakan empat pilihan jawaban, yaitu Sangat Sesuai (SS), Sesuai (S), Kurang Sesuai (KS), dan Tidak Sesuai (TS). Jawaban setiap item instrumen yang menggunakan skala likert mempunyai gradasi dari sangat positif sampai sangat negatif dan di beri skor. Dari masing-masing alternatif jawaban dan jenis butir pernyataan sudah terdapat skor yang ditentukan.

Untuk memudahkan penyusunan instrumen, maka digunakan kisi-kisi instrumen. Angket yang telah disusun, kemudian dilakukan uji coba kepada mahasiswa PGSD, ujicoba ini dilakukan untuk mengetahui apakah instrumen tersebut telah memenuhi syarat instrumen yang baik atau belum. Setelah instrumen angket diuji cobakan, maka dilakukan validitas empirik. Validitas empirik adalah validitas yang ditinjau dengan kriteria tertentu. Kriteria ini digunakan untuk menentukan tinggi rendahnya koefisien validitas alat evaluasi yang dibuat melalui perhitungan korelasi product moment. Validitas butir tes diuji dengan bantuan Microsoft Excel 2010. Dari 35 butir-butir pernyataan angket, sebanyak 32 butir pernyataan dinyatakan valid, 3 butir pernyataan dinyatakan tidak valid. Butirbutir pernyataan yang tidak valid tersebut dibuang dan tidak digunakan di dalam angket penelitian.
Suatu alat evaluasi disebut reliabel jika hasil evaluasi tersebut relatif tetap dan digunakan untuk subjek yang sama. Rumus yang digunakan untuk menghitung reliabilitas angket ini adalah rumus Spearman Brown atau Split half (Sugiono, 2014:131), dengan bantuan Microsoft Excel 2010. Hasil perhitungan reliabilitas diperoleh koefisien reliabilitas instrumen angket minat baca mahasiswa PGSD FKIP UIR adalah 0,94 yang menunjukkan tingkat reliabilitas sangat tinggi, artinya angket tersebut memenuhi karakteristik yang memadai untuk digunakan dalam penelitian. Kriteria reliabel angket mengartikan bahwa butirbutir pernyataan akan memberikan hasil yang sama jika diujikan kembali kepada mahasiswa lain.

Teknik analisis data yang dimaksud adalah untuk mencari jawaban atas pertanyaan yang sudah dirumuskan sebelumnya. Berdasarkan jenis penelitiannya, yaitu penelitian deskriptif analitis maka terdapat dua teknik analitis data hasil penelitian yang diperoleh yaitu data kuantitatif dan data kualitatif. Untuk mengetahui pengaruh program pojok literasi terhadap minat baca mahasiswa PGSD FKIP UIR, maka peneliti menggunakan analisis data regresi linear sederhana.

Analisis regresi digunakan untuk memprediksi seberapa jauh perubahan program pojok literasi terhadap minat baca mahasiswa. Sebelum analiis regresi digunakan maka diperlukan uji normalitas dan uji homogenitas. Persamaan umum regresi sederhana adalah

$$
\mathrm{Y}=\mathrm{a}+\mathrm{bX}
$$

Keterangan

$\mathrm{Y}=$ Subjek dalam variabel dependent yang

Diprediksikan

$\mathrm{X}=$ Subjek pada variabel independen yang 
122 Pengaruh Program Pojok Literasi Minat Baca Mahasiswa PGSD FKIP UIR - Febrina Dafit, Dea Mustika, Ningrum Melihayatri

mempunyai nilai tertentu

$\mathrm{a}=$ Harga $\mathrm{Y}$ ketika $\mathrm{X}=0$ (harga konstan)

$\mathrm{b}=$ Angka arah atau koefisien regresi, yang

menunjukkan angka

Data yang telah diregresikan kemudian dipaparkan berdasarkan jawaban responden. Data yang terkumpul kemudian dianalisis secara deskriptif yaitu dengan memaparkan data yang telah terkumpul sebagaimana adanya tanpa bermaksud membuat keputusan yang bersifat umum. Data-data yang telah dikumpulkan kemudian diolah dengan menggunakan rumus statistik sederhana yang dikemukakan Riduwan (2006:23), yaitu sebagai berikut:

$$
N A=\frac{P S}{S M} \times 100 \%
$$

Keterangan :

NA : Nilai akhir

PS : Perolehan skor

SM : Skor maksimum

Untuk menafsirkan besarnya persentase yang diperoleh dari hasil tabulasi data, digunakan penafsiran dengan kriteria yang dikemukakan oleh Riduwan (2006: 89) sebagai berikut.

Tabel 1. Interval Persentase dan Kategori

\begin{tabular}{|c|c|}
\hline$(\%)$ & Kategori \\
\hline $0-54$ & Sangat kurang \\
\hline $55-59$ & Kurang \\
\hline $60-74$ & Cukup \\
\hline $75-84$ & Baik \\
\hline $85-100$ & Sangat baik \\
\hline
\end{tabular}

Untuk menentukan presentase hasil penelitian adalah menggunakan rumus sebagai berikut (Sudijono, 2000; 43):

$$
P=\frac{F}{N} \times 100 \%
$$

Keterangan:

P: Presentase yang dicari ( frekuensi relatif)
F: Frekuensi

N: Jumlah Responden

\section{HASIL DAN PEMBAHASAN}

Berdasarkan hasil penelitian dari 37 orang pengunjung pojok literasi, diperoleh rata-rata minat baca mahasiswa adalah 107,39, minat baca paling rendah adah 89 dan paling tinggi adalah 122 dengan standar seviasi 7,95. Berikut disajikan tabel distribusi frekuensi data minat baca mahasiswa PGSD yang berkunjung ke pojok literasi.

Tabel 2. Distribusi Frekuensi Data Minat Baca Mahasiswa (Pojok Literasi)

\begin{tabular}{|c|c|c|c|}
\hline Nilai & $\mathbf{F}$ & $\boldsymbol{F}_{\boldsymbol{k}}$ & $\boldsymbol{F}_{\boldsymbol{r}}$ \\
\hline $89-94$ & 2 & 2 & 5,4 \\
\hline $95-100$ & 8 & 10 & 21,6 \\
\hline $101-106$ & 5 & 15 & 13,5 \\
\hline $107-112$ & 14 & 29 & 37,8 \\
\hline $113-118$ & 5 & 34 & 13,5 \\
\hline $119-124$ & 3 & 37 & 8,1 \\
\hline Total & 37 & & 100 \\
\hline
\end{tabular}

Untuk melihat pengaruh program pojok literasi, sebelum terbentuknya pojok literasi, maka peneliti mengambil data angket dari mahasiswa PGSD FKIP UIR. Angket yang diberikan adalah tentang minat baca. Jumlah mahasiswa untuk melihat minat baca mahasiswa adalah 37 orang. Dari 37 orang tersebut diperoleh rata-rata minat baca mahasiswa adalah 107,38, minat baca paling rendah adah 89 dan paling tinggi adalah 122 dengan standar seviasi 7,95

Uji normalitas data angket minat baca dilakukan dengan menggunakan uji statistik Kolmogorof Smirnov dengan taraf signifikansi 0,05. Uji normalitas dalam penelitian ini menggunakan hipotesis sebagai berikut: 
123 Pengaruh Program Pojok Literasi Minat Baca Mahasiswa PGSD FKIP UIR - Febrina Dafit, Dea Mustika, Ningrum Melihayatri

$\mathrm{H}_{0}$ : sampel berasal dari populasi berdistribusi normal

$\mathrm{H}_{1}$ : sampel berasal dari populasi berdistribusi tidak normal

Kriteria pengujian yang dilakukan yaitu $\mathrm{H}_{0}$ ditolak, jika nilai Sig. $(p$-value $)<\alpha($ dimana $\alpha$ $=0,05$ ).

Tabel 3. Hasil Uji Normalitas

\begin{tabular}{|c|c|c|c|}
\hline Kelp & \multicolumn{2}{|c|}{ Kolmogoro } & Kesimpula \\
& \multicolumn{2}{c|}{$\boldsymbol{v}$-Smirnov } & n \\
\cline { 2 - 3 } & $\mathbf{N}$ & Sig. & \\
\hline $\begin{array}{c}\text { Pojok } \\
\text { literasi }\end{array}$ & 37 & 0,200 & Terima $\mathrm{H}_{0}$ \\
\hline $\begin{array}{c}\text { Minat } \\
\text { baca }\end{array}$ & 37 & 0,200 & Terima $\mathrm{H}_{0}$ \\
\hline
\end{tabular}

Nilai signifikasi uji Kolmogorov-Smirnov minat baca yaitu 0,200 lebih besar dari $\alpha=0,05$. Dengan demikian $\mathrm{H}_{0}$ diterima, artinya pada taraf signifikan 5\% data angket minat baca mahasiswa PGSD FKIP UIR berdistribusi normal. Begitu juga dengan nilai signifikasi uji KolmogorovSmirnov jumlah kunjungan mahasiswa ke pojok literasi yaitu 0,200 lebih besar dari $\alpha=0,05$. Artinya pada taraf signifikan $5 \%$ data jumlah kunjungan mahasiswa berdistribusi normal.

Berdasarkan hasil uji homogenitas data angket dan kunjungan yang berdistribusi normal, maka dilakukan uji homogenitas. Uji homogenitas dilakukan untuk mengetahui apakah sampel berasal dari varians yang sama atau tidak. Untuk menguji homogenitas maka digunakan uji Levene Statistic dengan taraf signifikansi 0,05 dengan menggunakan hipotesis sebagai berikut:

$\mathrm{H}_{0} \quad: \sigma_{1}{ }^{2}=\sigma_{2}{ }^{2}$

$\mathrm{H}_{1} \quad: \sigma_{1}{ }^{2} \neq \sigma_{2}{ }^{2}$

Keterangan:

$\sigma_{1}=$ varians kelompok pojok literasi $\sigma_{2}=$ varians kelompok minat baca

Kriteria pengujian homogenitas yang digunakan yaitu jika nilai Sig. (p-value $)<\alpha(\alpha$ $=0,05)$, maka $\mathrm{H}_{0}$ ditolak sedangkan untuk kondisi lain $\mathrm{H}_{0}$ diterima. Nilai sig. Untuk kedua kelompok lebih besar dari 0,05 , yaitu 0,125 . Sehingga $\mathrm{H}_{0}$ diterima, artinya varians populasi data angket minat baca mahasiswa PGSD FKIP UIR homogen. Maka pengujian selanjutnya dilakukan regresi linear sederhana.

\section{Analisis Uji Regresi Linear Sederhana}

Analisis regresi sederhana bertujuan untuk mengetahui pengaruh program pojok literasi terhadap minat baca mahasiswa PGSD FKIP UIR. Besar pengaruh program pojok literasi terhadap minat baca dapat diamati menggunakan analisis regresi sederhana dengan prediktor data kategori (Sudjana, 2002:37). Pada penelitian ini peneliti menggunakan data angket minat baca mahasiswa yang pernah berkunjung ke pojok literasi dan data angket minat baca mahasiswa yang belum pernah berkunjung ke pojok literasi. Dengan adanya perbedaan data hasil angket minat baca mahasiswa tersebut dapat dilihat dan dicari menggunakan regresi sederhana.

Pada penelitian ini peneliti menggunakan data angket minat baca mahasiswa yang pernah berkunjung ke pojok literasi dan jumlah kunjungan mahasiswa ke pojok literasi. Dengan nilai $\mathrm{X}$ adalah jumlah mahasiswa yang datang ke pojok literasi sebagai variabel dependent dan $\mathrm{Y}$ adalah minat baca mahasiswa sebagai variabel independent. 
124 Pengaruh Program Pojok Literasi Minat Baca Mahasiswa PGSD FKIP UIR - Febrina Dafit, Dea Mustika, Ningrum Melihayatri

Tabel 4. Hasil Uji Regresi Sederhana Angket Minat Baca

\begin{tabular}{|c|c|c|c|c|c|}
\hline \multirow[t]{2}{*}{ Kelp } & \multicolumn{2}{|c|}{ Unst. Coef } & Stand & \multirow[t]{2}{*}{$\mathrm{t}$} & \multirow{2}{*}{$\begin{array}{c}\text { Sig } \\
\text {. }\end{array}$} \\
\hline & B & $\begin{array}{c}\text { Std. } \\
\text { Erro } \\
\mathrm{r}\end{array}$ & Beta & & \\
\hline $\begin{array}{c}\text { (Const } \\
\text { ) }\end{array}$ & $\begin{array}{r}87,9 \\
8\end{array}$ & , 857 & & $\begin{array}{l}102, \\
6\end{array}$ & ,000 \\
\hline pjkltr & 4,78 & , 197 & ,972 & 24,3 &, 000 \\
\hline
\end{tabular}

Dependent Variable: Minatbaca

Dari tabel di atas diperoleh persamaan regresi yaitu $\mathrm{Y}=87,981+4,785 \mathrm{X}$. Persamaan regresi tersebut digunakan sebagai dasar untuk memperkirakan program pojok literasi apakah valid atau tidak mempengaruhi minat baca mahasiswa. Maka dilakukan pengujian kevalidan persamaan regresi berdasarkan teknik probabilitas. Hipotesisnya adalah sebagai berikut:

$\mathrm{H}_{0}$ : tidak terdapat pengaruh program pojok literasi terhadap minat baca

$\mathrm{H}_{\mathrm{a}}$ : terdapat pengaruh program pojok literasi terhadap minat baca

Kriteria pengujian yang dilakukan yaitu $\mathrm{H}_{0}$ ditolak, jika nilai Sig. $(p$-value $)<\alpha(\alpha=0,05 / 2=$ 0,025). Dari tabel di atas diperoleh nilai Sig. ( $p$ value $=0,000$, yaitu $0,000<0,025$ maka $\mathrm{H}_{0}$ ditolak. Artinya terdapat pengaruh yang signifikan program pojok literasi terhadap minat baca mahasiswa PGSD FKIP UI.

Penyebaran data angket kepada 37 orang mahasiswa berfungsi untuk mendapatkan data tentang minat baca mahasiswa yang telah berkunjung ke pojok literasi. Berikut diuraikan hasil dari minat baca mahasiswa setelah mengunjungi pojok literasi.

Semangat dalam membaca buku. Jumlah pernyataan angket yang diberikan untuk melihat semangat mahasiswa dalam membaca buku adalah 4 pernyataan. Dari hasil 37 responden, diperoleh rata-rata semangat dalam membaca buku adalah 13,49. Pada pernyataan pertama mahasiswa yang menyatakan sangat sesuai adalah sebanyak 24 orang, sesuai 8 orang, dan kurang sesuai 5 orang. Artinya 86,5\% mahasiswa adalah orang yang suka membaca dan 13,5\% mahasiswa adalah orang yang kurang suka dan tidak suka membaca.

Pada pernyataan kedua, 30 orang menyatakan sangat sesuai, 4 orang menyatakan sesuai, 2 orang kurang sesuai, dan 1 orang tidak sesuai. Artinya 91,9\% mahasiswa meluangkan waktu untuk membaca dan $8,1 \%$ mahasiswa adalah orang yang kurang dan tidak meluangkan waktu untuk membaca buku. Pada pernyataan ketiga 9 orang mahasiswa menyatakan sesuai, 7 orang mahasiswa menyatakan kurang sesuai, dan 21 orang mahasiswa menyatakan tidak sesuai. Artinya 75,68\% mahasiswa menyatakan kurang sesuai dan tidak sesuai dinyatakan kriteria orang yang tidak suka membaca buku.

Pada pernyataan keempat, 15 orang menyatakan sesuai, 9 orang kurang sesuai, dan 13 orang menyatakan tidak sesuai jarang sekali membaca buku di pojok literasi. Artinya 59,5\% mahasiswa menyatakan kurang sesuai dan tidak sesuai dikatakan jarang sekali membaca buku di pojok literasi.

a. Kesadaran sebagai mahasiswa untuk membaca buku

Jumlah pernyataan angket yang diberikan untuk melihat kesadaran sebagai mahasiswa untuk membaca buku adalah 4 pernyataan. Dari hasil 37 responden, diperoleh rata-rata kesadaran sebagai mahasiswa untuk membaca buku adalah 
11,49. Pada pernyataan kelima mahasiswa yang menyatakan sangat sesuai adalah sebanyak 19 orang, sesuai 7 orang, kurang sesuai 8 orang, dan tidak sesuai 3 orang. Artinya 70,27\% mahasiswa suka duduk di pojok literasi untuk membaca buku-buku tentang perkuliahan dan 29,73\% mahasiswa kurang suka dan tidak suka duduk di pojok literasi untuk membaca bukubuku tentang perkuliahan.

Pada pernyataan keenam, 6 orang menyatakan sangat sesuai, 13 orang menyatakan sesuai, 9 orang kurang sesuai, dan 9 orang tidak sesuai. Artinya 48,64\% tidak sesuai dan kurang sesuai meminjam buku di pojok literasi ketika ada perintah dari dosen. Sedangkan 51,36\% mahasiswa menyatakan sangat sesuai dan sesuai meminjam buku di pojok literasi hanya ketika ada perintah dari dosen. Pada pernyataan ketujuh, 2 orang menyatakan sangat sesuai, 9 orang menyatakan ssuai, 16 orang kurang sesuai, dan 10 orang tidak sesuai. Artinya 29,73\% mahasiswa menyatakan sangat sesuai dan sesuai membaca buku di pojok literasi hanya ketika ada tugas. Sedangkan $70,27 \%$ lagi menyatakan kurang sesuai dan tidak sesuai bahwa mahasiswa membaca buku di pojok literasi hanya ketika ada tugas.

Pada pernyataan kedelapan, 13 orang menyatakan sangat sesuai, 13 orang menyatakan sesuai, 4 orang menyatakan kurang sesuai, dan 7 orang menyatakan tidak sesuai. Artinya 70,28\% mahasiswa menyatakan sangat sesuai dan sesuai bahwa sebagai seorang mahasiswa harus banyak membaca buku. Sedangkan 29,72\% lagi menyatakan kurang sesuai dan tidak sesuai bahwa sebagai seorang mahasiswa harus banyak membaca buku.
Kesadaran akan pentingnya buku. Jumlah pernyataan angket yang diberikan untuk melihat kesadaran akan pentingnya buku adalah 4 pernyataan. Dari hasil 37 responden, diperoleh rata-rata kesadaran akan pentingnya buku adalah 14,03. Pada pernyataan kesembilan mahasiswa yang menyatakan sangat sesuai adalah sebanyak 24 orang, sesuai 11 orang, dan kurang sesuai 2 orang. Artinya 94,59\% menyatakan sangat sesuai dan sesuai bahwa banyak membaca buku untuk memperluas wawasan pengetahuan. Sedangkan 5,41\% menyatakan kurang sesuai dan tidak sesuai bahwa membaca buku untuk memperluas wawasan pengetahuan.

Pada pernyataan kesepuluh, mahasiswa yang menyatakan sangat sesuai adalah 16 orang, sesuai 3 orang, 11 orang kurang sesuai, dan 7 orang tidak sesuai. Artinya 51,32\% menyatakan sangat sesuai dan sesuai suka membaca koran, artikel atau tulisan di mading karena memuat informasi penting. Sedangkan 48,68\% menyatakan kurang sesuai dan tidak sesuai bahwa mereka suka membaca koran, artikel atau tulisan di mading karena memuat informasi penting.

Pada pernyataan kesebelas, mahasiswa yang menyatakan sangat sesuai 1 orang dan tidak sesuai 36 orang. Artinya 97,3\% mahasiswa menyatakan tidak sesuai bahwa membaca buku tidak sepenting bermain game online, sedangkan 2,7\% menyatakan sangat sesuai bahwa membaca buku tidak sepenting bermain game online. Pada pernyataan keduabelas, mahasiswa yang menyatakan kurang sesuai 9 orang dan tidak sesuai 28 orang. Artinya, 100\% mahasiswa menyatakan kurang sesuai dan tidak sesuai bahwa membaca buku ketika akan ujian saja. 
Ketertarikan untuk membaca buku. Jumlah pernyataan angket yang diberikan untuk melihat ketertarikan untuk membaca buku adalah 3 pernyataan. Dari hasil 37 responden, diperoleh rata-rata ketertarikan untuk membaca buku adalah 10,22. Pada pernyataan ketigabelas mahasiswa yang menyatakan sangat sesuai adalah sebanyak 21 orang, sesuai 7 orang, kurang sesuai 5 orang, dan tidak sesuai 4 orang. Artinya $75,68 \%$ menyatakan sangat sesuai dan sesuai bahwa mereka merasa telah banyak membaca dibandingkan teman-temannya. Sedangkan $24,32 \%$ menyatakan kurang sesuai dan tidak sesuai bahwa mereka telah banyak membaca dibandingkan teman-temannya.

Pada pernyataan keempatbelas mahasiswa yang menyatakan sangat sesuai adalah 25 orang, sesuai 10 orang, dan kurang sesuai 2 orang. Artinya 94,6\% menyatakan sangat sesuai dan sesuai bahwa setiap hari mereka selalu menyempatkan membaca buku walaupun hanya beberapa menit saja. Sedangkan $5,4 \%$ menyatakan kurang sesuai setiap hari setiap hari mereka selalu menyempatkan membaca buku walaupun hanya beberapa menit saja.

Pada pernyataan kelimabelas, mahasiswa yang menyatakan sangat sesuai 3 orang, sesuai 1 orang, kurang sesuai 12 orang, dan tidak sesuai 21 orang. Artinya, 10,81\% mahasiswa menyatakan sangat sesuai dan sesuai bahwa lebih suka mencari sumber bacaan dari internet daripada membaca buku. Sedangkan 89,19\% menyatakan kurang sesuai dan tidak sesuai lebih suka mencari sumber bacaan dari internet dari pada membaca buku

Ketertarikan terhadap buku bacaan. Jumlah pernyataan angket yang diberikan untuk melihat ketertarikan terhadap buku bacaan adalah 4 pernyataan. Dari hasil 37 responden, diperoleh rata-rata ketertarikan untuk membaca buku adalah 13,19. Pada pernyataan keenambelas mahasiswa yang menyatakan sangat sesuai adalah sebanyak 32 orang, sesuai 4 orang, dan kurang sesuai 1 orang. Artinya 97,3\% menyatakan sangat sesuai dan sesuai bahwa mereka selalu membaca buku di pojok literasi saat jam istirahat. Sedangkan 2,7\% menyatakan kurang sesuai bahwa selalu membaca buku di pojok literasi saat jam istirahat.

Pada pernyataan ketujuhbelas mahasiswa yang menyatakan sangat sesuai 7 orang, sesuai 12 orang, kurang sesuai 4 orang, tidak sesuai 14 orang. Artinya 51,35\% mahasiswa menyatakan sangat sesuai dan sesuai tidak suka meminjam buku dari pojok literasi. Sedangkan 48,65\% menyatakan kurang sesuai dan tidak sesuai dikatakan tidak suka meminjam buku dari pojok literasi.

Pada pernyataan kedelapanbelas, mahasiswa yang menyatakan sangat sesuai 22 orang, sesuai 9 orang, kurang sesuai 3 orang, tidak sesuai 3 orang. Artinya, 83,78\% menyatakan sangat sesuai dan sesuai bahwa sudah banyak buku yang pernah dibaca/dipinjam dari pojok literasi. Sedangkan 16,22\% menyatakan kurang sesuai dan tidak sesuai sudah banyak buku yang pernah dibaca/dipinjam dari pojok literasi.

Pada pernyataan kesembilanbelas, mahasiswa yang menyatakan sangat sesuai 1 orang, sesuai 7 orang, kurang sesuai 8 orang, tidak sesuai 21 orang. Artinya, 21,62\% menyatakan sangat sesuai dan sesuai dikatakan sangat senang gameonline atau akses media sosial daripada membaca artikel atau materi 
127 Pengaruh Program Pojok Literasi Minat Baca Mahasiswa PGSD FKIP UIR - Febrina Dafit, Dea Mustika, Ningrum Melihayatri

perkuliahan. Sedangkan $78,38 \%$ menyatakan tidak sesuai dan kurang dikatakan sangat senang gameonline atau akses media sosial daripada membaca artikel atau materi perkuliahan.

Memanfaatkan waktu untuk membaca buku. Jumlah pernyataan angket yang diberikan untuk melihat memanfaatkan waktu untuk membaca buku adalah 5 pernyataan. Dari hasil 37 responden, diperoleh rata-rata memanfaatkan waktu untuk membaca buku adalah 18,24.

Pada pernyataan keduapuluh, mahasiswa yang menyatakan tidak sesuai 27 orang, kurang sesuai 9 orang, dan sesuai 1 orang. Artinya 97,3\% menyatakan tidak sesuai dan kurang sesuai dikatakan jarang sekali membaca buku di pojok literasi ketika istirahat. Sedangkan 2,7\% menyatakan sesuai dikatakan jarang sekali membaca buku di pojok literasi ketika istirahat.

Pada pernyataan keduapuluhsatu, mahasiswa yang menyatakan sangat sesuai 35 orang, sesuai 2 orang dan tidak ada yang menyatakan kurang sesuai dan tidak sesuai. Artinya $100 \%$ mahasiswa menyatakan sangat sesuai dan sesuai selalu menggunakan waktu luang di kampus / di rumah/ di kos untuk membaca buku, koran atau majalah. Pada pernyataan keduapuluhdua mahasiswa yang menyatakan sangat sesuai 18 orang, sesuai 10 orang, dan kurang sesuai 9 orang. Artinya $75,68 \%$ menyatakan sangat sesuai dan sesuai bahwa semenjak adanya pojok literasi pengetahuan mereka tentang pembelajaran di SD lebih banyak. Sedangkan 24,32\% menyatakan kurang sesuai bahwa semenjak adanya pojok literasi pengetahuan mereka tentang pembelajaran di SD lebih banyak.
Pada pernyataan keduapuluhtiga, 21 orang menyatakan sangat sesuai, 15 orang sesuai, dan 1 orang menyatakan kurang sesuai. Artinya 97,3\% mahasiswa menyatakan senang membaca buku dimanapun berada. Sedangkan 2,7\% menyatakan kurang sesuai menyatakan senang membaca buku dimanapun berada. Pada pernyataan keduapuluhempat, mahasiswa yang menyatakan sangat sesuai 32 orang, sesuai 4 orang, dan kurang sesuai 1 orang. Artinya 97,3\% menyatakan sangat sesuai dan sesuai membaca buku di pojok literasi ketika ada waktu luang. Sedangkan 2,7\% menyatakan tidak sesuai membaca buku di pojok literasi ketika ada waktu luang.

Memilih buku bacaan. Jumlah pernyataan angket yang diberikan untuk melihat memilih buku bacaan adalah 3 pernyataan. Dari hasil 37 responden, diperoleh rata-rata memilih buku bacaan adalah 9,7. Pada pernyataan keduapuluhlima, mahasiswa yang menyatakan sangat sesuai 1 orang, sesuai 17 orang, kurang sesuai 10 orang, dan tidak sesuai 9 orang. Artinya, 51,35\% mahasiswa menyatakan kurang sesuai dan tidak sesuai bahwa lebih suka membaca materi perkuliahan via handphone daripada buku. Sedangkan 48,65\% menyatakan sangat sesuai dan sesuai bahwa lebih suka membaca materi perkuliahan via handphone daripada buku.

Pada pernyataan keduapuluhenam, mahasiswa yang menyatakan sesuai 8 orang, kurang sesuai 11 orang, 18 orang tidak sesuai. Artinya, 78,38\% mhasiswa meyatakan lebih suka membaca tentang fiksi daripada nonfiksi. Sedangkan 21,62\% menyatakan sesuai lebih suka membaca tentang fiksi daripada nonfiksi. 
128 Pengaruh Program Pojok Literasi Minat Baca Mahasiswa PGSD FKIP UIR - Febrina Dafit, Dea Mustika, Ningrum Melihayatri

Pada pernyataan keduapuluhtujuh, mahasiswa yang menyatakan sangat sesuai 27 orang, sesuai 9 orang, dankurang sesuai 1 orang. Artinya, 97,29\% mahasiswa menyatakan sangat sesuai dan sesuai bahwa lebih suka mencari informasi melalui buku dan majalah dibandingkan dari internet. Sedangkan 2,7\% menyatakan kurang sesuai lebih suka mencari informasi melalui buku dan majalah dibandingkan dari internet.

Keinginan mencari sumber bacaan buku. Jumlah pernyataan angket yang diberikan untuk melihat keinginan mencari sumber bacaan buku adalah adalah 5 pernyataan. Dari hasil 37 responden, diperoleh rata-rata melihat keinginan mencari sumber bacaan buku adalah 17,03. Pada pernyataan keduapuluhdelapan, mahasiswa yang menyatakan sangat sesuai 27 orang, sesuai 5 orang, dan tidak sesuai 5 orang. Artinya 86,48\% mahasiswa mengatakan sangat sesuai dan sesuai bahwa mahasiswa suka mengunjungi pojok literasi untuk membaca buku. Sedangkan $13,52 \%$ mahasiswa menyatakan tidak sesuai bahwa mereka suka mengunjungi pojok literasi untuk membaca buku.

Pada pernyataan keduapuluhsembilan, mahasiswa yang menyatakan sangat sesuai 3 orang, sesuai 12 orang, kurang sesuai 4 orang, dan tidak sesuai 18 orang. Artinya 40,59\% mahasiswa mengatakan sangat sesuai dan sesuai bahwa mereka membaca buku sekali sebulan atau bahkan dua bulan sekali. Sedangkan 59,41 mengatakan kurang sesuai dan tidak sesuai bahwa mereka membaca buku sekali sebulan atau bahkan dua bulan sekali.

Pada pernyataan ketigapuluh, mahasiswa yang menyatakan sangat sesuai 18 orang, sesuai
10 orang, dan kurang sesuai 9 orang. Artinya 75,68 mahasiswa mengatakan sangat sesuai dan sesuai bahwa pojok literasi membantu mereka untuk mendapatkan sumber bacaan tentang materi perkuliahan. Sedangkan 24,32\% mengatakan kurang sesuai dan tidak sesuai bahwa pojok literasi membantu mereka untuk mendapatkan sumber bacaan tentang materi perkuliahan

Pada pernyataan ketigapuluhsatu, mahasiswa yang menyatakan sesuai adalah 5 orang, kurang sesuai 11 orang, dan tidak sesuai 21 orang. Artinya 86,49\% mahasiswa menyatakan tidak sesuai dan kurang sesuai bahwa mereka lebih suka menghabiskan waktu nongrong dengan teman dibandingkan membaca buku. Sedangkan $13,51 \%$ mahasiswa menyatakan sesuai bahwa mereka lebih suka menghabiskan waktu nongrong dengan teman dibandingkan membaca buku.

Pada pernyataan ketigapuluhdua, mahasiswa yang menyatakan sangat sesuai 34 orang, sesuai 2 orang, dan kurang sesuai 1 orang. Artinya 97,3\% mahasiswa menyatakan sangat sesuai dan sesuai bahwa pengetahuan yang diperoleh lebih banyak dari membaca buku. Sedangkan 2,7\% menyatakan kurang sesuai bahwa pengetahuan yang diperoleh lebih banyak dari membaca buku.

Pengembangan minat baca mahasiswa melalui pojok literasi mempunyai beberapa manfaat antara lain: Pertama, pojok literasi dapat merangsang mahasiswa untuk lebih gemar membaca dan memiliki daya pikir yang baik. Kedua, untuk mendekatkan buku pada mahasiswa. Ketiga, setiap saat mahasiswa bisa membaca buku tanpa harus mondar mandir ke perpustakaan universitas, sebab di lorong program studi PGSD FKIP UIR sudah tersedia Jurnal Basicedu Vol 4 No 1 Januari 2020 p-ISSN 2580-3735 e-ISSN 2580-1147 
129 Pengaruh Program Pojok Literasi Minat Baca Mahasiswa PGSD FKIP UIR - Febrina Dafit, Dea Mustika, Ningrum Melihayatri

buku-buku yang dibutuhkan untuk proses perkuliahan. Keempat, dosen dapat menjadikan pojok literasi sebagai bagian dari kegiatan perkuliahan.

Diharapkan dengan adanya pojok literasi akan memberikan kesadaran kepada mahaasiswa akan manfaat membaca buku dan literatur serta dapat meningkatkan minat baca. Kesadaran akan pentingnya berliterasi akan membuka mata bahwa dengan membiasakan diri membaca dapat mengubah hidup dan jalan pikiran. Tinggi rendahnya minat baca suatu bangsa amat menentukan kualitas sumber daya manusia, sedangkan kualitas sumber daya manusia sangat menentukan perkembangan suatu bangsa.

\section{UCAPAN TERIMA KASIH}

Terimakasih kepada Lembaga Penelitian dan Pengabdian Masyarakat (LPPM) Universitas Islam Riau (UIR) yang telah mendanai penelitian ini dengan.

\section{SIMPULAN}

Secara umum penelitian ini bertujuan untuk melihat mendeskripsikan pengaruh pojok literasi terhadap minat baca mahasiswa PGSD FKIP UIR. Terdapat delapan indikator pernyataan angket yang diberikan pada mahasiswa. Dari paparan data dan hasil penelitian, serta pembahasan dapat disimpulkan bahwa terdapat pengaruh yang signifikan pojok literasi terhadap minat baca mahasiswa, dimana kategori minat baca mahasiswa adalah baik dengan persentase $83,89 \%$.

\section{DAFTAR PUSTAKA}

Abidin, Y. (2014). Desain sistem pembelajaran dalam konteks kurikulum 2013. Bandung: Refika Aditama
Arikunto, Suharsimi. 2012. Dasar-dasar Evaluasi Pendidikan. Jakarta: Bumi Aksara

Asif Alfarik. Menumbuhkan Budaya Literasi Di Kalangan Pelajar. https://publikasiilmiah.ums.ac.id/xmlui/bitst ream/handle/11617/8951/i53.pdf?sequence $=1$

Deni Hardianto. Studi tentang minat baca mahasiswa fakultas ilmu pendidikan UNY http://staffnew.uny.ac.id/upload/132310873 /penelitian/Studi+Tentang+Minat+Baca+M ahasiswa+FIP+UNY 0.pdf

Esti Swatika Sari dan Setyawan Pujiono. 2017. Budaya Literasi Di Kalangan Mahasiswa FBS UNY. Jurnal Litera, volume 16, nomor 1. (Online).

(https://www.researchgate.net/publication/3 18230950_BUDAYA_LITERASI_DI_KA LANGAN_MAHASISWA_FBS_UNY/do wnload)

Faradina, Nidya. 2017. Pengaruh Gerakan Literasi terhadap Minat Baca Siswa di SD Islam Terpadu Muhammadyah An-Najah Jatinom Klaten. Jurnal Hanata Widya, Volume 6 Nomor 8. (Online). ()

Morocco, CC. (2008). Supported literacy for adolescents: transforming teaching and content learning for the twenty-first century. San Fransisco: Jossey-Bass A Wiley Imprint.

Pawit M. Yusuf. (2007). Pedoman Penyelenggaraan Perpustakaan Sekolah, Jakarta: Prenada Media Grup.

Rahim, Farida. 2007. Pengajaran Membaca di Sekolah Dasar. Jakarta: Bumi Aksara

Riley, J. (2006). Language and literacy 3-7, creative approaches to teaching. London: SAGE Publications.

Siswati. 2010. Minat Membaca Pada Mahasiswa (Studi Deskriptif Pada Mahasiswa Fakultas Psikologi Undip Semester 1 https://ejournal.undip.ac.id/index.php/psikol ogi/article/viewFile/2957/2643

Slameto. 2003. Belajar dan Faktor-faktor yang Mempengaruhinya. Jakarta: Bina Aksara.

Sugiyono. 2014. Metode Penelitian Kualitatif, Kuantitatif, R\&D. Bandung: Alfabeta 
130 Pengaruh Program Pojok Literasi Minat Baca Mahasiswa PGSD FKIP UIR - Febrina Dafit, Dea Mustika, Ningrum Melihayatri

Surya, Muhamad. 1999. Dalam Proses Belajar Mengajar. Bandung: PT Remaja Rosda Karya.

Syah, Muhibbin. 2004. Psikologi Pendidikan, Bandung : PT Remaja Rosda Karya

Sudjana, Nana. (2002). Dasar-dasar Proses Belajar Mengajar. Bandung: Sinar Baru Algesi 